https://doi.org/10.30910/turkjans.680042

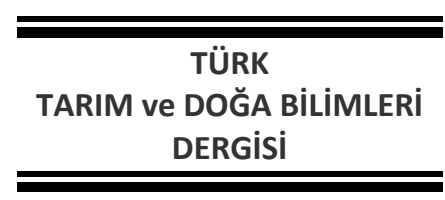

\section{Determination of Characteristics of Dry Bean Lines Hybridized by Line $\mathbf{x}$ Tester Method and the Effect of Heredity ${ }^{\S}$ \\ Research Article}

TURKISH

JOURNAL of AGRICULTURAL and NATURAL SCIENCES

www.dergipark.gov.tr/turkjans

\author{
Şemsi TAMÜKSEK*, Ercan CEYHAN \\ Department of Field Crops, Faculty of Agriculture, Selcuk University, Konya, Turkey \\ *Corresponding author: demircan.semsi18@gmail.com
}

\begin{abstract}
Received: 04.07.2019
Received in Revised: 04.11.2019

Accepted: 18.11 .2019

Abstract

In this study, two dry beans (Phaseolus vulgaris L.) (Great Northern 59 and Alberto) and a bombay bean (Phaseolus coccineus L.) (testers) were crossed with five bean genotypes (Phaseolus vulgaris L. PV04001, PV05023, PV04042, PV04026 and PV04032) (lines). F1 hybrids obtained by the line $x$ tester method (5x3). This experiment were established in a a randomized block design with three replicates in the fully controlled Selcuk University Plant Breeding Greenhouse. The effects of non- additive gene and heritability were found to be low. The heterosis and heterobeltiosis values of the F1 generations were positive for seed yield.
\end{abstract}

Key words: Bean, seed yield, line $\mathrm{x}$ tester method, combining ability, heterosis.

\title{
Line x Tester Metoduyla Islah Edilen Kuru Fasulye Hatlarının Özelliklerinin Belirlenmesi ve Kalıtımın Etkisi
}

\begin{abstract}
Özet
Araştırmada, tester olarak iki adet kuru fasulye (Phaseolus vulgaris L.) (Great Northern 59 ve Alberto) çeşidi ve bir adet bombay fasulyesi (Phaseolus coccineus L.) ve ana olarak ise 5 fasulye (PV04001, PV05023, PV04042, PV04026 ve PV04032) hattı arasında melezleme yapılmıştır. Bu çalışma Line x Tester metoduna göre $F_{1}$ melezleri elde edilmiştir. Bu araştırma Tesadüf Blokları Deneme desenine göre üç tekerrürlü olarak tam kontrollü Selçuk Üniversitesi Deneme serasında kurulmuştur. $F_{1}$ generasyonunda tane verimi için eklemeli olmayan gen etkileri ve dar anlamda kalıtım dereceleri düşük olarak tespit edilmiştir. $F_{1}$ generasyonunda heterosis ve heterobeltiosis değerleri tane verimi için pozitif olmuştur.
\end{abstract}

Anahtar kelimeler: Fasulye, tane verimi, line $x$ tester analizi, kombinasyon yeteneği, heterosis.

\section{Introduction}

The bean Phaseolus vulgaris L. belongs to the Leguminosae family, members of which produce dry edible legumes that are grown and consumed worldwide. Legumes are a very important source of protein, starch, cellulose and minerals for human nutrition (Aykroyd et al., 1982) and contribute to nitrogen fixation, thus increasing the efficiency of production systems with positive effects on environmental sustainability (Şehirali, 1988).

Breeding studies of beans are generally carried out via selection. However, other approaches are needed to increase genetic variation in beans (Ceyhan, 2003), such as hybridization. This approach can be used to improve productivity, quality and resistance to diseases. The generation of gene resources that can be used to address these factors is the main subject of breeding studies (Ceyhan, 2003). Line $x$ tester analysis has been used in many crossbreeding programmes, because the breeders present genetic characteristics about quantitative properties (Ceyhan, 2003). Line $x$ tester analysis provides information to breeders about heterosis and the general combination ability (GCA) and specific combination ability of parents (SCA) (Ceyhan et al., 2008). The effects of hybridization 
on heritability can also be estimated (Ceyhan, 2003). Previous breeding studies have found that seed yield and harvest index in beans are under the influence of additive genes (Zimmermann et al., 1985; Singh and Urrea, 1994), while the number of ovaries per pod is a single gene allele and under the effect of additive gene (Al-Mukhtar and Coyne, 1981). In contrast, pod properties and plant height are under the influence of nonadditive genes (Rodrigues et al., 1998).

The aim of this study was to determine the general and special combination capabilities, heterosis and heterobeltiosis values, and the degree of heritability in the broad and narrow sense in the F1 generations of beans using the line $x$ tester method, and then to find high-adapt, efficient and high-quality genotypes for the development of new lines.

\section{Materials and Methods}

In this study, two dry beans (Phaseolus vulgaris L.) (Great Northern 59 and Alberto) and a bombay bean (Phaseolus coccineus L.) were used as testers and five bean genotypes (Phaseolus vulgaris L.) were used as lines. The characteristics of the parents are shown in Table 1 . The Alberto and Great Northern 59 varieties used in this study are the most cultivated and earliest varieties grown in the region (GTHB, 2018).

Table 1. The characteristics of the parents used in breeding.

Parents Characteristics of the Parents

It is 50-60 cm long. Broad beans are flat, light green, without awn. Seed dermason type and

PV04001 color is white. The average vegetation period is 110-125 days. The average yield per decare is $150-250 \mathrm{~kg}$. Protein content is between $24-26 \%$. white. The average vegetation period is 115-120 days. The average yield per decare is $200-$ $280 \mathrm{~kg}$. Protein content is between $19-23 \%$.

It is an early and leechy dwarf bean line. The pods are smooth, medium long, green and

PV04026 awned. Seeds are round and white in color. The average vegetation period is 90-100 days. Average yield per decare is $200-300 \mathrm{~kg}$. Protein content is between $19-23 \%$.

It has a height of $50 \mathrm{~cm}$, white flower color, broad bean shape, dermason type and white PV04032 seed color. The average vegetation period is 120-130 days. Average yield per decare is 250$300 \mathrm{~kg}$. Protein content is between $20-23 \%$.

It grows upright and grows to $55-60 \mathrm{~cm}$. The flower color is white, pod shape is flat and seed

PV05023 has white color. The average vegetation period is $110-120$ days. The average yield per decare is $200-280 \mathrm{~kg}$. Protein content is between $22-25 \%$.

Semi dwarf, plant height $60-70 \mathrm{~cm}$, no pods opening, flower color is white, yield $280-300 \mathrm{~kg}$

Alberto $\mathrm{da}^{-1}$, dermason type, pod shape flat-end curved, resistant to viruses and bacterial diseases. The average vegetation period is 110-120 days.

Phaseolus It grown as an ornamental plant. Length up to 3 meters. The beans are bright, showy, with coccineus L. white and red flowers. Pods are larger and longer. The bones are hard and thick.

Great Medium-sized, kidney-shaped flat white seed. Its yield is very high and it is an early variety. Northern 59 The average seed yield of this variety is $150-200 \mathrm{~kg} \mathrm{da}^{-1}$. The average vegetation period is $90-$ 100 days.

Eight bean genotypes were sown on four different dates at 10-day intervals starting from 25 October 2016 in a fully controlled greenhouse in the Department of Field Crops, Faculty of Agriculture, Selcuk University. Ten seeds of each parent were sown in rows $2 \mathrm{~m}$ long. The hybridization process was performed as described by Ceyhan (2003) and Ceyhan et al. (2014).

The breeding process was performed using the line $x$ tester method and gave $15(5 \times 3)$ hybrid combinations. At least 30 seeds were obtained from each of the 15 hybrid combinations. The obtained hybrid seeds and parents were grown under greenhouse conditions again. The greenhouse experiment was established using a randomized block design with three replicates in 1 $\mathrm{m}$ long plots on 30 March 2017. Harvesting was carried out in August. During the study, $15 \mathrm{~kg}$ DAP (Diammonium Phosphate) fertilizer was applied to the whole experimental area in a uniform manner to meet the needs of the hybrids and the parents. Weed control was performed by hand and drip irrigation was given five times depending on the water demand of the plants. During cultivation, the greenhouse was kept constant at a daytime temperature of $25 \mathrm{o}$, night temperature of $18 \stackrel{\circ}{\circ}$, relative humidity $50-55 \%$ and wind speed $5 \mathrm{~km} / \mathrm{h}$. Data collected from observation, measurement and analysis on F1 plants were subjected to a preliminary variance analysis using 
the MSTAT-C Statistics Program according to the randomized block design. Line $x$ tester analysis was applied to the properties that showed variation among hybrids of between $1 \%$ and $5 \%$ significance (Kempthorne, 1957; Sing and Chaudhary, 1979). General and special combination ability effect and variance Griffing (1956), heritability Stansfield (1969), in the calculation of the percentage values of heterosis and heterobeltiosis Fonseca and Pattersan (1968), in the determination of the relations between the properties Yurtsever (1984) were utilized.

\section{Results and Discussion}

The line $x$ tester analysis of variance of the investigated characteristics in the study revealed that the squares averages of the hybrids were statistically significant for all traits. Significant differences were found between genotypes in all investigated characteristics (Table 2). In the $F_{1}$ generation, the hybrids showed variation in all properties studied, except for the number of seeds per plant, at the $1 \%$ significance level. Significant differences were observed between lines for plant height and protein content. Among the tester plants, plant height, seed yield, plant weight, and protein content were significantly different. In the line $\mathrm{x}$ tester interaction, significant differences were found for all properties except protein content.

Table 2. The average of squares calculated by line $x$ tester method for seed yield and its components in $F_{1}$ hybrids of beans.

\begin{tabular}{|c|c|c|c|c|c|}
\hline $\begin{array}{l}\text { Source of } \\
\text { variation }\end{array}$ & DF & Plant height & $\begin{array}{c}\text { Number of pods } \\
\text { per plant }\end{array}$ & $\begin{array}{c}\text { Number of } \\
\text { seeds per pod }\end{array}$ & $\begin{array}{c}\text { Number of seeds per } \\
\text { plant }\end{array}$ \\
\hline Replication & 2 & 5.058 & 22.464 & 0.099 & 945,255 \\
\hline Treatments & 22 & $1480.808 * *$ & $76.557^{* *}$ & $1.436 * *$ & $3220,578 * *$ \\
\hline Parents & 7 & $3718.994 * *$ & 12.995 & $2.200 * *$ & $1248,157 * *$ \\
\hline Hybrids & 14 & $466.260 * *$ & $29.442 * *$ & $0.757 * *$ & 890,954 \\
\hline Par vs Hyb & 1 & 17.165 & $1181.100 * *$ & $5.593 * *$ & $49642,260 * *$ \\
\hline Line & 4 & $213.578 * *$ & 17.105 & 0.226 & 128,080 \\
\hline Tester & 2 & $2460.556^{* *}$ & 21.848 & 0.047 & 564,846 \\
\hline Line vs Tester. & 8 & $94.028 * *$ & $37.509 * *$ & $1.200 * *$ & $1353,918 * *$ \\
\hline Error & 44 & 26.316 & 9.722 & 0.109 & 375,179 \\
\hline $\begin{array}{l}\text { Source of } \\
\text { variation }\end{array}$ & DF & Seed yield & 100 -seed weight & \multicolumn{2}{|c|}{ Protein content } \\
\hline Replication & 2 & 111.862 & $22.755^{* *}$ & \multicolumn{2}{|r|}{0.088} \\
\hline Treatments & 22 & $772.198 * *$ & $375.431 * *$ & \multicolumn{2}{|r|}{$4.069 * *$} \\
\hline Parents & 7 & 40.311 & $571.670 * *$ & \multicolumn{2}{|r|}{1.319} \\
\hline Hybrids & 14 & $572.687^{* *}$ & $297.409 * *$ & \multicolumn{2}{|c|}{$3.895^{* *}$} \\
\hline Par vs Hyb & 1 & $8688.559 * *$ & $94.054 * *$ & \multicolumn{2}{|c|}{$25.760 * *$} \\
\hline Line & 4 & 443.272 & 216.181 & \multicolumn{2}{|c|}{$8.558^{* *}$} \\
\hline Tester & 2 & $1592.219 * *$ & $1284.078 * *$ & \multicolumn{2}{|r|}{$3.647^{*}$} \\
\hline Line vs Tester. & 8 & $382.512 * *$ & $91.356 * *$ & \multicolumn{2}{|r|}{1.626} \\
\hline Error & 44 & 56.419 & 2.676 & \multicolumn{2}{|r|}{0.841} \\
\hline
\end{tabular}

$*: p<0.05 ; * *: p<0.01$

The average seed yield of the parents ranged from 28.04 to $38.80 \mathrm{~g}$, and the 100 -seed weight ranged from 30.17 to $70.17 \mathrm{~g}$. Plant height, number of pods per plant, number of seeds per pod, and number of seeds per plant ranged from 49.33 to $153.33 \mathrm{~cm}, 14.77$ to $20.77,2.67$ to 5.23 , and 41.29 to 110.14 , respectively. Protein content ranged from $23.18 \%$ to $25.12 \%$.

The average seed yield of the $F_{1}$ hybrids varied from 36.82 to $88.55 \mathrm{~g}$, average plant height from 55.33 to $93.67 \mathrm{~cm}$, average number of pods per plant from 21.37 to 32.20 , average number of seeds per pod from 4.53 to 6.10 , average number of seeds per plant from 113.95 to 170.84 , average 100-seed weight from 29.00 to $61.43 \mathrm{~g}$, and average protein content from $23.53 \%$ to $27.20 \%$. Plant height (Genchev, 1995; Ceyhan, 2004; Ulker and Ceyhan, 2008a; Ceyhan et al., 2012), number of pods (Ceyhan, 2004; Varankaya, 2011), the number of seeds per pod (Anlarsal et al., 2000; Ulker and Ceyhan 2008a), the number of seeds per plant (Düzdemir, 1998; Ulker and Ceyhan, 2008a), seed yield (Saraç and Sehirali 1989; Pekşen and Gulumser 2005) and protein content (Duzdemir, 1998; Ulker and Ceyhan 2008b) were similar to the findings of other studies.

In terms of the investigated properties the $(H / D)^{1 / 2}$ ratio was greater than 1 and the 
$\sigma^{2} \mathrm{GCA} / \sigma^{2} \mathrm{SCA}$ ratio was less than 1 , showing that a non-additive dominant gene effect influences these characteristics (Table 3). This indicates that selection can be started from the next generation on investigated properties. At the same time, the number of pods, number of seeds per pod and number of seeds per plant were found to be influenced by an additive gene effect in the $F_{1}$ generation (Table 3 ). It has been found that investigated properties are under the effect of additive and non-additive genes. Some investigators (Singh and Urrea, 1994; Oliveira Junior et al., 1997) stated that additive genes influence seed yield in beans, while others (Barelli et al., 2000) reported that non-additive genes influence seed yield. Other researchers obtained similar results (Saraç and Şehirali, 1989; Bozoğlu, 1995; Ceyhan, 2004; Ulker and Ceyhan, 2008a).

Table 3. Estimation of GCA variance, estimation of SCA variance estimation, additive variance, proportional relationship with dominance variance, broad and narrow inheritance in parents and $F_{1}$ hybrids of beans.

\begin{tabular}{|c|c|c|c|c|c|c|c|c|}
\hline Features & $\sigma^{2} \mathbf{G C A}$ & $\sigma^{2} \mathbf{S C A}$ & $\begin{array}{c}\sigma^{2} \mathbf{G C A} / \\
\sigma^{2} \mathbf{S C A}\end{array}$ & $\sigma^{2} \mathbf{D}$ & $\sigma^{2} \mathbf{H}$ & $(H / D)^{1 / 2}$ & $\mathrm{H}^{2}$ & $h^{2}$ \\
\hline Plant height & 7.825 & 298.802 & 0.026 & 15.649 & 22.571 & 1.201 & 94.36 & 33.30 \\
\hline $\begin{array}{l}\text { Number of pods per } \\
\text { plant }\end{array}$ & -0.170 & 5.255 & ---- & -0.339 & 9.262 & ---- & 66.98 & -2.79 \\
\hline $\begin{array}{l}\text { Number of seeds per } \\
\text { pod }\end{array}$ & -0.009 & 0.127 & --- & -0.019 & 0.364 & ---- & 85.64 & -4.88 \\
\hline $\begin{array}{l}\text { Number of seeds per } \\
\text { plant }\end{array}$ & -9.732 & 102.368 & ---- & -19.464 & 326.246 & --- & 57.89 & -4.51 \\
\hline Seed yield & 3.998 & 249.860 & 0.016 & 7.995 & 108.697 & 3.687 & 90.15 & 5.90 \\
\hline 100-seed weight & 4.331 & 175.954 & 0.025 & 8.663 & 29.560 & 1.847 & 78.40 & 22.15 \\
\hline Protein content & 0.048 & 1.256 & 0.038 & 0.095 & 0.261 & 1.655 & 78.40 & 14.97 \\
\hline
\end{tabular}

Table 4. Means in terms of properties examined in the parents and $F_{1}$ hybrids of beans.

\begin{tabular}{lccccccc}
\hline \multicolumn{1}{c}{ Parents } & $\begin{array}{c}\text { Plant } \\
\text { height }\end{array}$ & $\begin{array}{c}\text { Number } \\
\text { of pods } \\
\text { per plant }\end{array}$ & $\begin{array}{c}\text { Number } \\
\text { of seeds } \\
\text { per pod }\end{array}$ & $\begin{array}{c}\text { Number } \\
\text { of seeds } \\
\text { per plant }\end{array}$ & $\begin{array}{c}\text { Seed } \\
\text { yield }\end{array}$ & $\begin{array}{c}\text { 100-seed } \\
\text { weight }\end{array}$ & $\begin{array}{c}\text { Protein } \\
\text { content }\end{array}$ \\
\hline PV04001 & 54.00 & 19.57 & 4.90 & 97.16 & 38.80 & 30.90 & 30.90 \\
PV04042 & 55.33 & 18.80 & 5.10 & 98.08 & 37.88 & 35.90 & 35.90 \\
PV04026 & 52.33 & 17.83 & 4.90 & 88.74 & 32.73 & 33.93 & 33.93 \\
PV04032 & 54.67 & 15.40 & 5.07 & 79.10 & 28.04 & 32.80 & 32.80 \\
PV05023 & 49.33 & 16.47 & 5.13 & 86.37 & 31.17 & 32.17 & 32.17 \\
Alberto & 55.33 & 20.77 & 5.23 & 110.14 & 35.86 & 30.17 & 30.17 \\
Phaseolus coccineus L. & 153.33 & 14.77 & 2.67 & 41.29 & 36.43 & 71.17 & 71.17 \\
Great Northern 59 & 56.67 & 16.70 & 5.13 & 88.30 & 32.67 & 31.37 & 31.37 \\
F1 Hybrids & & & & & & & \\
PV04001 x Alberto & 55.67 & 24.93 & 5.77 & 145.65 & 51.04 & 34.47 & 34.47 \\
PV04001 x P. coccineus L. & 73.67 & 25.03 & 4.53 & 115.02 & 69.60 & 59.37 & 59.37 \\
PV04001 x Great Northern 59 & 59.00 & 29.13 & 5.33 & 158.46 & 61.15 & 38.00 & 38.00 \\
PV04042 x Alberto & 59.67 & 24.57 & 4.87 & 121.41 & 36.82 & 29.00 & 29.00 \\
PV04042 x P. coccineus L. & 70.67 & 21.37 & 5.70 & 125.34 & 50.40 & 37.97 & 37.97 \\
PV04042 x Great Northern 59 & 58.67 & 27.57 & 6.10 & 170.84 & 61.22 & 34.70 & 34.70 \\
PV04026 x Alberto & 59.33 & 25.63 & 5.90 & 152.34 & 59.45 & 37.73 & 37.73 \\
PV04026 x P. coccineus L. & 81.33 & 30.37 & 4.80 & 148.44 & 80.55 & 53.27 & 53.27 \\
PV04026 x Great Northern 59 & 62.33 & 29.00 & 4.87 & 144.80 & 49.96 & 33.87 & 33.87 \\
PV04032 x Alberto & 60.33 & 32.20 & 5.13 & 167.68 & 55.63 & 32.40 & 32.40 \\
PV04032 x P. coccineus L. & 91.67 & 23.63 & 6.00 & 142.78 & 58.74 & 39.93 & 39.93 \\
PV04032 x Great Northern 59 & 55.33 & 21.73 & 5.13 & 113.95 & 38.63 & 33.10 & 33.10 \\
PV05023 x Alberto & 62.67 & 25.97 & 5.33 & 141.90 & 50.22 & 34.53 & 34.53 \\
PV05023 x P. coccineus L. & 93.67 & 23.90 & 5.93 & 145.32 & 88.55 & 61.43 & 61.43 \\
PV05023 x Great Northern 59 & 67.33 & 28.33 & 5.07 & 143.00 & 54.37 & 36.50 & 36.50 \\
\hline
\end{tabular}

Based on the general combination abilities of the $F_{1}$ generation for particular characteristics, the following pairs were found to be suitable parents: PV05023 and Phaseolus coccineus L. for 
plant height; PV04026 and Phaseolus coccineus L. for the number of pods; PV04042 and Phaseolus coccineus L. for number of seeds per pod; PV04026, PV05023 and Phaseolus coccineus L. for seed yield; and PV04001 and Phaseolus coccineus L. for protein content (Table 5). PV04026, PV05023 and Phaseolus coccineus L. genotypes, which are superior in seed yield, can be used in breeding programmes to improve seed yield.

Considering the special combination capabilities of hybrids in $F_{1}$ generation, for plant height "PV04032 x Phaseolus coccineus L." hybrid; for the number of pods "PV04032 x Alberto" and "PV04026 x Phaseolus coccineus L." hybrids; for number of seeds per pod "PV04001 x Alberto", "PV04042 x Great Northem 59", "PV04026 x Alberto","PV04032 x Phaseolus coccineus L." and “PV05023 x Phaseolus coccineus L." hybrids; for number of seeds per plant "PV04042 x Great Northem 59" and "PV04032 x Alberto" hybrids; for seed yield "PV04042 x Great Northem 59", "PV04032 x Alberto" and "PV05023 x Phaseolus coccineus L" hybrids; for protein content "PV04032 x Alberto" hybrid were positive (Table 5). The GCA and SCA effects of parents and hybrids on the number of pods per plant were determined by AlMukhtar and Coyne (1981), Ceyhan (2003) and Ceyhan et al. (2008). These researchers have obtained similar results to our findings. Many other studies have been done on the effect of GCA and SCA on beans and have determined the combinations of parents and hybrids with different numbers of significant GCA and SCA for seed yield in the investigated generations (Oliveira Junior et al., 1997; Barelli et al., 2000).

Table 5. GCA values in parents of beans and SCA values in $\mathrm{F}_{1}$ hybrids of beans.

\begin{tabular}{|c|c|c|c|c|c|c|c|}
\hline Parents & $\begin{array}{l}\text { Plant } \\
\text { height }\end{array}$ & $\begin{array}{l}\text { Number } \\
\text { of pods } \\
\text { per plant }\end{array}$ & $\begin{array}{l}\text { Number } \\
\text { of seeds } \\
\text { per pod }\end{array}$ & $\begin{array}{l}\text { Number } \\
\text { of seeds } \\
\text { per plant }\end{array}$ & $\begin{array}{l}\text { Seed } \\
\text { yield }\end{array}$ & $\begin{array}{c}\text { 100-seed } \\
\text { weight }\end{array}$ & $\begin{array}{l}\text { Protein } \\
\text { content }\end{array}$ \\
\hline PV04001 & $-4.644 * *$ & 0.141 & -0.153 & -2.752 & 2.841 & $4.194 * *$ & $1.375^{* *}$ \\
\hline PV04042 & $-4.422 * *$ & -1.724 & $0.191^{*}$ & -3.266 & $-8.274^{* *}$ & $-5.862 * *$ & -0.111 \\
\hline PV04026 & 0.244 & $2.109 *$ & -0.176 & 6.067 & $5.564 * *$ & $1.871^{* *}$ & $-0.581^{*}$ \\
\hline PV04032 & 1.689 & -0.369 & 0.058 & -0.992 & $-6.755^{* *}$ & $-4.607 * *$ & 0.474 \\
\hline PV05023 & $7.133^{* *}$ & -0.158 & 0.080 & 0.944 & $6.625^{* *}$ & $4.404^{* *}$ & $-1.157 * *$ \\
\hline Alberto & $-7.889 * *$ & 0.436 & 0.036 & 3.334 & $-7.122 * *$ & $-6.125^{* *}$ & -0.228 \\
\hline Phaseolus coccineus L. & $14.778 * *$ & -1.364 & 0.029 & -7.082 & $11.814 * *$ & $10.643^{* *}$ & $0.566 * *$ \\
\hline Great Northern 59 & $-6.889 * *$ & 0.928 & -0.064 & 3.748 & $-4.691 * *$ & $-4.519 * *$ & -0.338 \\
\hline \multicolumn{8}{|l|}{$F_{1}$ Hybrids } \\
\hline PV04001 x Alberto & 0.778 & -1.868 & $0.520 * *$ & 2.605 & -2.432 & $-3.354 * *$ & -0.207 \\
\hline PV04001 x P. coccineus L. & -3.889 & 0.032 & $-0.707^{* *}$ & -17.606 & -2.811 & $4.784^{* *}$ & -0.147 \\
\hline PV04001 x Great Northern 59 & 3.111 & 1.836 & 0.187 & 15.001 & 5.243 & -1.430 & 0.354 \\
\hline PV04042 x Alberto & 4.556 & -0.369 & $-0.724 * *$ & $-21.124^{*}$ & -5.540 & 1.236 & 0.299 \\
\hline PV04042 x P. coccineus L. & $-7.111 * *$ & -1.769 & 0.116 & -6.775 & $-10.892 * *$ & $-6.566 * *$ & -0.088 \\
\hline PV04042 x Great Northern 59 & 2.556 & 2.138 & $0.609 * *$ & $27.899 * *$ & $16.432 * *$ & $5.330 * *$ & -0.211 \\
\hline PV04026 x Alberto & -0.444 & $-3.136^{*}$ & $0.676 * *$ & 0.479 & 3.256 & $2.236 * *$ & -0.401 \\
\hline PV04026 x P. coccineus L. & -1.111 & $3.398 *$ & $-0.418^{* *}$ & 6.995 & 5.416 & 1.001 & 0.519 \\
\hline PV04026 x Great Northern 59 & 1.556 & -0.262 & -0.258 & -7.474 & $-8.672 *$ & $-3.237 * *$ & -0.117 \\
\hline PV04032 x Alberto & -0.889 & $5.909 * *$ & -0.324 & $22.878^{*}$ & $11.751 * *$ & $3.380 * *$ & -0.906 \\
\hline PV04032 x P. coccineus L. & $7.778 * *$ & -0.858 & $0.549 * *$ & 8.391 & -4.071 & $-5.854 * *$ & 0.544 \\
\hline PV04032 x Great Northern 59 & $-6.889 * *$ & $-5.051 * *$ & -0.224 & $-31.269 * *$ & $-7.680 *$ & $2.474^{* *}$ & 0.362 \\
\hline PV05023 x Alberto & -4.000 & -0.536 & -0.147 & -4.838 & -7.035 & $-3.498 * *$ & $1.215^{* *}$ \\
\hline PV05023 x P. coccineus L. & 4.333 & -0.802 & $0.460 * *$ & 8.995 & $12.359 * *$ & $6.634^{* *}$ & -0.828 \\
\hline PV05023 x Great Northern 59 & -0.333 & 1.338 & -0.313 & -4.158 & -5.323 & $-3.137 * *$ & -0.387 \\
\hline
\end{tabular}

* $: p<0.05$; $^{* *}: p<0.01$

\section{Conclusions}

The estimates of heterosis and heterobeltiosis were calculated as the percentage increase and decrease over values for all traits studied. The heterosis of the $15 \mathrm{~F}_{1}$ hybrids ranged from $-32.27 \%$ to $27.04 \%$ for plant height, from $5.81 \%$ to $55.17 \%$ for number of seeds per pod, from $-0.13 \%$ to $162.02 \%$ for seed yield, from -
$29.08 \%$ to $22.04 \%$ for 100 -seed weight, and from $2.13 \%$ to $12.14 \%$ for protein content. The heterobeltiosis of the $15 \mathrm{~F}_{1}$ hybrids ranged from $53.91 \%$ to $18.82 \%$ for plant height, from $-7.48 \%$ to $18.83 \%$ for number of seeds per pod, from $-2.79 \%$ to $143.10 \%$ for seed yield, from $-46.65 \%$ to $21.14 \%$ for 100 -seed weight, and from $-3.91 \%$ to $10.52 \%$ for protein content. Ceyhan (2003) and Ceyhan et 
al. (2008) reported high or low heterosis and heterobeltiosis levels. The fact that the average heterosis and heterobeltiosis values were negative in the $F_{1}$ generation indicates that the effects of non-additive genes are important for investigated properties.

As a result, selection in future generations may produce promising genotypes that can be used in different breeding programmes.

Table 6. Heterosis (\%) values of the properties examined in $F_{1}$ generation.

\begin{tabular}{|c|c|c|c|c|c|c|c|}
\hline F1 hybrids & $\begin{array}{l}\text { Plant } \\
\text { height }\end{array}$ & $\begin{array}{c}\text { Number } \\
\text { of pods } \\
\text { per } \\
\text { plant }\end{array}$ & $\begin{array}{l}\text { Number } \\
\text { of seeds } \\
\text { per pod }\end{array}$ & $\begin{array}{c}\text { Number of } \\
\text { seeds per } \\
\text { plant }\end{array}$ & $\begin{array}{l}\text { Seed } \\
\text { yield }\end{array}$ & $\begin{array}{c}\text { 100-seed } \\
\text { weight }\end{array}$ & $\begin{array}{l}\text { Protein } \\
\text { content }\end{array}$ \\
\hline PV04001 x Alberto & 1.83 & 23.64 & $13.82 * *$ & 40.53 & 36.74 & $12.88^{* *}$ & $8.87^{* *}$ \\
\hline PV04001 x P. coccineus L. & $-28.94 * *$ & $45.83 * *$ & $19.82^{* *}$ & 66.16 & $85.04^{* *}$ & $16.34 * *$ & $10.55^{* *}$ \\
\hline PV04001 x Great Northern 59 & 6.63 & $60.64 * *$ & $6.31^{* *}$ & 70.89 & 71.12 & $22.04 * *$ & $11.96 * *$ \\
\hline PV04042 x Alberto & 7.83 & $24.18 * *$ & $-5.81 * *$ & 16.62 & -0.13 & $-12.21 * *$ & $6.11^{* *}$ \\
\hline PV04042 x P. coccineus L. & $-32.27 * *$ & 27.31 & $46.78 * *$ & 79.87 & 35.67 & $-29.08 * *$ & $6.01 * *$ \\
\hline PV04042 x Great Northern 59 & 4.76 & $55.31 * *$ & $19.22 * *$ & 83.33 & 73.57 & 3.17 & $4.68 * *$ \\
\hline PV04026 x Alberto & 10.22 & $32.82 * *$ & $16.45^{* *}$ & 53.20 & 73.36 & $17.73 * *$ & $-1.77^{*}$ \\
\hline PV04026 x P. coccineus L. & $-20.91 * *$ & $86.30 * *$ & $26.87^{* *}$ & 128.32 & $132.94 * *$ & 1.36 & $3.48 * *$ \\
\hline PV04026 x Great Northern 59 & 14.37 & $67.95^{* *}$ & $-2.99 * *$ & 63.59 & 52.76 & 3.73 & 0.01 \\
\hline PV04032 x Alberto & 9.70 & $78.06 * *$ & -0.32 & 77.22 & 74.13 & 2.91 & $4.58 * *$ \\
\hline PV04032 x P. coccineus L. & -11.86 & $56.69 * *$ & $55.17^{* *}$ & 137.20 & 82.25 & $-23.18^{* *}$ & $12.14^{* *}$ \\
\hline PV04032 x Great Northern 59 & -0.60 & $35.41 * *$ & 0.65 & 36.15 & 27.27 & 3.17 & $10.71 * *$ \\
\hline PV05023 x Alberto & 19.75 & $39.48 * *$ & $2.89 * *$ & 44.42 & 49.87 & $10.80 * *$ & $4.69 * *$ \\
\hline PV05023 x P. coccineus L. & -7.57 & $53.04 * *$ & $52.14 * *$ & 127.66 & $162.02 * *$ & $18.90 * *$ & $-2.13^{* *}$ \\
\hline PV05023 x Great Northern 59 & $27.04 * *$ & $70.85^{* *}$ & $-1.30 * *$ & 40.53 & 36.74 & $12.88 * *$ & $8.87^{* *}$ \\
\hline Average & -0.12 & 48.92 & 15.73 & 69.89 & 66.01 & 3.37 & 4.65 \\
\hline LSD $_{\% 5}$ & 8.687 & 5.280 & 0.558 & 32.801 & 12.720 & 2.770 & 1.553 \\
\hline LSD $_{\% 1}$ & 7.192 & 4.371 & 0.462 & 27.155 & 10.530 & 2.293 & 1.286 \\
\hline
\end{tabular}

* $: p<0.05 ; * *: p<0.01$

Table 7. Heterobeltiosis (\%) values of the properties examined in $\mathrm{F}_{1}$ generation.

\begin{tabular}{lccccccc}
\hline \multicolumn{1}{c}{ F1 hybrids } & $\begin{array}{c}\text { Plant } \\
\text { height }\end{array}$ & $\begin{array}{c}\text { Number } \\
\text { of pods } \\
\text { per plant }\end{array}$ & $\begin{array}{c}\text { Number } \\
\text { of seeds } \\
\text { per pod }\end{array}$ & $\begin{array}{c}\text { Number of } \\
\text { seeds per } \\
\text { plant }\end{array}$ & $\begin{array}{c}\text { Seed } \\
\text { yield }\end{array}$ & $\begin{array}{c}\text { 100-seed Protein } \\
\text { weight } \\
\text { content }\end{array}$ \\
\hline PV04001 x Alberto & 0.60 & 20.06 & $10.19^{* *}$ & $32.24^{* *}$ & $31.55^{* *}$ & $11.54^{* *}$ & $8.66^{* *}$ \\
PV04001 x P. coccineus L. & $-51.96^{* *}$ & $27.94^{* *}$ & -7.48 & 18.39 & $79.38^{* *}$ & $-16.57^{* *}$ & $8.96^{* *}$ \\
PV04001 x Great Northern 59 & 4.12 & $48.88^{* *}$ & 3.90 & $63.10^{* *}$ & $57.60^{* *}$ & $21.14^{* *}$ & $10.52^{* *}$ \\
PV04042 x Alberto & 7.83 & 18.30 & -7.01 & 10.23 & -2.79 & $-19.22^{* *}$ & 5.02 \\
PV04042 x P. coccineus L. & $-53.91^{* *}$ & 13.65 & $11.76^{* *}$ & $27.79^{* *}$ & $33.07^{* *}$ & $-46.65^{* *}$ & 3.24 \\
PV04042 x Great Northern 59 & 3.53 & $46.63^{* *}$ & $18.83^{* *}$ & $74.19^{* *}$ & $61.64^{* *}$ & -3.34 & 4.59 \\
PV04026 x Alberto & 7.23 & $23.43^{* *}$ & $12.74^{* *}$ & $38.32^{* *}$ & $65.81^{* *}$ & $11.20^{* *}$ & -3.65 \\
PV04026 x P. coccineus L. & $-46.96^{* *}$ & $70.28^{* *}$ & -2.04 & $67.28^{* *}$ & $121.13^{* *}$ & $-25.15^{* *}$ & 3.17 \\
PV04026 x Great Northern 59 & 10.00 & $62.62^{* *}$ & -5.19 & $63.18^{* *}$ & $52.62^{* *}$ & -0.20 & -2.96 \\
PV04032 x Alberto & 9.04 & $55.06^{* *}$ & -1.91 & $52.25^{* *}$ & $55.15^{* *}$ & -1.22 & 2.46 \\
PV04032 x P. coccineus L. & $-40.22^{* *}$ & $53.46^{* *}$ & $18.42^{* *}$ & $80.51^{* *}$ & $61.26^{* *}$ & $-43.89^{* *}$ & $8.12^{* *}$ \\
PV04032 x Great Northern 59 & -2.35 & $30.14^{* *}$ & 0.00 & 29.05 & 18.24 & 0.91 & $9.67^{* *}$ \\
PV05023 x Alberto & $13.25^{* *}$ & $25.04^{* *}$ & 1.91 & $28.84^{* *}$ & $40.07^{* *}$ & $7.36^{* *}$ & 4.48 \\
PV05023 x P. coccineus L. & $-38.91^{* *}$ & $45.14^{* *}$ & $15.58^{* *}$ & $68.25^{* *}$ & $143.10^{* *}$ & $-13.68^{* *}$ & -3.91 \\
PV05023 x Great Northern 59 & $18.82^{* *}$ & $69.66^{* *}$ & -1.30 & $61.95^{* *}$ & $66.41^{* *}$ & $13.47^{* *}$ & -2.22 \\
Average & -10.70 & $\mathbf{3 9 . 9 5}$ & $\mathbf{3 . 8 8}$ & $\mathbf{4 5 . 5 6}$ & $\mathbf{5 6 . 8 5}$ & $\mathbf{- 7 . 7 2}$ & $\mathbf{3 . 1 7}$ \\
\hline
\end{tabular}


§: This article is summarized from Şemsi TAMÜKSEK's Master Thesis.

\section{References}

Al-Mukhtar, F.A., Coyne, D.P. 1981. Inheritance and association of flower ovule, seed, pod and maturity characters in dry edible beans (Phaseolus vulgaris L.). Journal of the American Society for Horticultural Science, 106 (6): 713-719.

Anlarsal, A.E., Yücel, C., Özveren, D. 2000. Çukurova koşullarında bazı fasulye (Phaseolus vulgaris L.) çeşitlerinde tane verimi ve verimle ilgili özellikler ile bu özellikler arası ilişkilerin saptanması. Turk J Agric For, 24: 19-29.

Aykroyd, W.R., Doughty, J., Walker, A.F. 1982. Legumes in human nutrition (Vol. 20). Food \& Agriculture Org., p.152.

Barelli, M.A., Goncalves-Vidigal, M.C., Amaral Junior, A.T.D., Vidigal Filho, P.S., Scapim, C.A., Sagrilo, E. 2000. Diallel Analysis for Grain Yield and Yield Components in Phaseolus vulgaris L. Acta Scientiarum, 22 (4): 883-887.

Bozoğlu, H. 1995. Kuru fasulyede (Phaseolus vulgaris L.) bazı tarımsal özelliklerin genotip $x$ çevre interaksiyonu ve kalıtım derecelerinin belirlenmesi üzerine bir araştırma. Doktora Tezi. Samsun, 99.

Ceyhan, E. 2003. Bezelye ebeveyn ve melezlerinde bazı tarımsal özelliklerin ve kalıtımlarının çoklu dizi analiz metoduyla belirlenmesi. Selçuk Üniversitesi Fen Bilimleri Enstitüsü.

Ceyhan, E. 2004. Effect of sowing dates on some yield components and yield of dry bean (Phaseolus vulgaris L.) cultivars. Turkish Journal of Field Crops, 9 (2): 87-95.

Ceyhan, E., Harmankaya, M., Avcl, M. A. 2008. Effects of sowing dates and cultivars on protein and mineral contents of bean (Phaseolus vulgaris L.). Asian Journal of Chemistry, 20 (7): 5601.

Ceyhan E., Kahraman A., Ateş M.K., Karadaş S. 2012. Stability analysis on seed yield and its components in pea. Bulg. J. Agric. Scie, 18 (6): 887-893.

Ceyhan E., Kahraman A. 2013. Genetic analysis of yield and some characters in peas. Legume Research, 36 (4): 273-279.

Ceyhan, E., Kahraman, A., Avcı, M.A., Dalgıç, H. 2014. Combining ability of bean genotypes estimated by Line $x$ Tester analysis under highly-calcareous soils. The Journal of Animal and Plant Sciences, 24 (29): 579-584.

Düzdemir, O. 1998. Kuru fasulye (Phaseolus vulgaris L.) genotiplerinde verim ve diğer bazı özellikler üzerine bir araştırma. Gaziosmanpaşa Üniversitesi. Fen Bilimleri Enst. Yüksek Lisans Tezi, Tokat.

Fonseca, S., Pattersan, F.L. 1968. Hybrid vigor in a seven parent diallel cross in common winter wheat. Crop Science, 8: 85-88.

Genchev, D. 1995. Assessment of tolerance to stress factors in breeding material of kidney beans (Phaseolus vulgaris L.). Bulgarian Journal of Agricultural Science, 1 (4): 415422.

Griffing, B. 1956. Concept of general and specific combining ability in relation to diallel crossing systems. Australian Journal of Biological Sciences, 9: 463-493.

GHTB. 2018. Tarımsal Veriler. Ankara: T.C. Gıda, Hayvancılık ve Tarım Bakanlığı.

Kempthorne, O. 1957. An Introduction to Genetic Statitic. New York. Wiley and Sons, p.545.

Oliveira Junior, A., Miranda, G., Cruz, C. 1997. Evaluation of the combining ability of dry bean cultivars based on unbalanced circulating and partial diallel crossing systems. Revista Ceres (Brazil).

Pekşen, E., Gülümser, A. 2005. Bazı fasulye (Phaseolus vulgaris L.) genotiplerinde verim ve verim unsurları arasındaki ilişkiler ve path analizi. OMÜ Zir. Fak. Dergisi, 20(3):82-87.

Rodrigues, R., Leal, N.R., Perera, M.G. 1998. Diallel analysis of six agronomic traits in Phaseolus vulgaris L. Bragantia, 57 (2): 241-250.

Saraç, A., Şehirali, S. 1989. Fasulyede ekim zamanı ve sıra aralığının verim ve verim öğeleri üzerine etkileri. Ankara Üniversitesi Fen Bilimleri Enstitüsü, Ankara.

Sing, R.K., Chaudhary, B. D. 1979. Line $x$ Tester Analysis. In : Biometrical Methods in Quantitative Genetic Analysis. New Delhi. Kalyani Publishers, p. 205-214.

Singh, S.P., Urrea, C.A. 1994. Selection for seed yield and other traits among early generations of intra and interracial populations of the common bean. Brasileira de Genetica, 17 (3): 299-303.

Stansfield, W.D. 1969. Theory and Problems of Genetics. New York, McGraw-Hill Book Company, p.281.

Şehirali, S. 1988. Yemeklik Dane Baklagiller. Ankara Üniversitesi Ziraat Fakültesi, p. 435.

Ülker, M., Ceyhan, E. 2008a. Orta anadolu ekolojik şartlarında yetiştirilen fasulye (Phaseolus vulgaris L.) genotiplerinin bazı tarımsal özelliklerinin belirlenmesi. Selçuk Üniversitesi Ziraat Fakültesi Dergisi, 22 (46): 77-89.

Ülker, M., Ceyhan, E. 2008b. Orta anadolu ekolojik şartlarında yetiştirilen fasulye (Phaseolus 
vulgaris L.) genotiplerinin protein ve bazı mineral oranlarının belirlenmesi. Selçuk Üniversitesi Ziraat Fakültesi Dergisi, 22 (46): 90-97.

Varankaya, S. 2011. Yozgat ekolojik şartlarında yetiştirilen fasulye (Phaseolus vulgaris L.) genotiplerinin bazı tarımsal özelliklerinin belirlenmesi. Selçuk Üniversitesi Fen Bilimleri Enstitüsü.

Yıldırım, M.B. 1985. Populasyon Genetiği. İzmir, Ege Üniversitesi Ziraat Fakültesi Yayınları, p.

Yurtsever, N. 1984. Deneysel istatistik metotlar. Tarım Orman ve Köyişleri Bakanlığı Köy Hizmetleri Genel Müdürlüğü.

Zimmermann, M.D.O., Rosielle, A., Foster, K., Waines, J. 1985. Gene action for grain yield and harvest index of common bean grown as sole crop and in intercrop with maize. Field Crops Research, 12: 319-329. 